\title{
COVID-19 IMPACT ON E.COMMERCE USAGE
}

\author{
Antanas Usas \\ Lithuanian Sport university, Lithuania \\ E-mail: Antanas.Usas@lsu.lt \\ Edmundas Jasinskas \\ Lithuanian Sport university, Lithuania \\ E-mail: Edmundas.Jasinskas@lsu.lt \\ Viktoriia Zagurska-Antoniuk \\ Zhytomyr Polytechnic State University, Ukraine \\ E-mail: kgn.zvf@gmail.com \\ Vladyslav Savitskyi \\ Zhytomyr Polytechnic State University, Ukraine \\ E-mail: savitskiy_vladislav@ukr.net \\ Pavlina Fuhelo \\ State Agrarian and Engineering University in Podilya, Ukraine \\ E-mail: Ole18@meta.ua \\ Submission: 8/3/2021 \\ Revision: 9/14/2021 \\ Accept: 9/26/2021
}

\section{ABSTRACT}

Online stores, ad portals, shopping apps have become part of everyday life in 2020-2021. The Covid-19 epidemic has rapidly forced numerous entities (public, business, and private) to become predominantly oriented to electronic commerce in the last few months (Pejić-Bach, 2021). Business in the online space faces new challenges that require additional knowledge and skills. The object of the research is the assessment how covid-19 impact on ecommerce usage in Lithuania. The aim of the work is to examine ecommerce usage in Lithuania during covid-19 pandemic. Methods: scientific literature analysis, statistical data analysis. Businesses had to offer a wider range of services in order to survive. The issue of cybersecurity has grown. Consumers have also reacted ambiguously to this situation. Not only are economic factors that determine the frequency or quantity of consumer purchases distinguished, but also social and psychological factors, such as 
DOI: 10.14807/ijmp.v12i6.1750

loss of motivation or apathy. The vast majority of Lithuanian shoppers were selling local online shops. The amount of money spent on online shopping has also increased. The pandemic has increased the scope of ecommerce and the range of services in Lithuania despite the deteriorating economic and social situation.

Keywords: ecommerce; covid-19 impact; ecommerce usage; ecommerce in Lithuania

\section{INTRODUCTION}

The Covid-19 pandemic has wreaked considerable havoc around the world. The increasing number of new cases and the worsening situation of patients have forced heads of state to react. Declared quarantines, emergency situations and curfews forced businesses to look for different solutions to stay in the market. As a result of the pandemic situation, the owners of physical shops had to suspend their activities at least temporarily.

According to the European Central Bank (2021), euro area GDP contracted by a total of $6.6 \%$ in 2020 , while annual headline inflation, which was $1.2 \%$ in 2019 , fell to $0.3 \%$. The Covid-19 epidemic has rapidly forced numerous entities (public, business, and private) to become predominantly oriented to electronic commerce in the last few months (Pejić-Bach, 2021).

Online stores, ad portals, shopping apps have become part of everyday life in 20202021. In ecommerce certain product and service categories were particularly popular during pandemic, increasing turnover sometimes and even tens of times, while demand for some nonfirst necessity goods decreased or remained unchanged. Ecommerce transactions revealed that sales of anti-virus purchases: disinfectant, gloves, face masks and antibacterial sprays increased by a staggering $817 \%$.

According to different sources consumers rushed to provide not only the recommended protections against coronavirus - medicines for colds, cough, flu also increased by $198 \%$ and painkillers by $152 \%$. The pandemic has highlighted the basic needs to bridge the digital functionality within and across the countries; digital platforms have given the solution to many problems (Galhotra \& Dewan, 2020). Such a move to the online space required considerable material resources. Around $€ 3.7$ trillion has been allocated to fight the pandemic and boost business in Europe, according to the European Union Commission (2021).

Although some of this money has already reached business, it does not guarantee the survival of businesses in the market. The socioeconomic tragedy required the complete 
DOI: 10.14807/ijmp.v12i6.1750

mobilization of governments, companies, and other organizations to contain and combat the disease (da Silva, Sugahara \& Ferreira, 2021). Business in the online space faces new challenges that require additional knowledge and skills. More than a year after the start of the pandemic, can we look at how the forced transformation of business has affected the online shopping market?

The object of the research is the assessment how covid-19 impact on Ecommerce usage in Lithuania.

The pandemic has accelerated the online services towards a more digital inclusion and changes in consumer's online shopping behaviors. Digital platforms were the best option for people to be connected and track latest news. Not all business and consumers were ready for that. Different business types had some struggles to switch to online business. Most of the business already had their social networks but not fully functional ecommerce websites.

According to Ho, Phan and Le-Hoang (2021) with the development of the Internet and social networking platforms such as Facebook, Instagram, Youtube ..., before shopping, consumers can exchange information, advice, or receive advice from many different sources. All of these things could help consumer to pick the right choice in case of purchase. Nevertheless, to know that during the pandemic, lots of new and inexperience's consumers storm the online shops.

The move to the Internet space is not confined to only learning but it has explored the wings in the entertainment like gaming, subscription-based platforms, Social Media / YouTube channels, Health care sector has also emerged with the digital movement as the health-related applications for the Doctor advice or ordering the medicines online is considered to be the most used applications during the Lockdown phase (Galhotra \& Dewan, 2020).

According to Silva, Sugahara and Ferreira (2021) the situation faced by the pandemic showed that it is necessary to invest more in the sector of human health and well-being. Ecommerce could help to encourage consumers to take right decisions towards purchasing and well-being.

\section{LITERATURE REVIEW}

The pandemic and the constant progress of information communication technologies encourage businesses to make bold decisions. Many businesses are at risk from how their target audience will react when deploying ICT services. 
DOI: $10.14807 /$ ijmp.v12i6.1750

According Černikovaite and Karazijienė (2021) during the pandemic, it was observed that the pandemic caused by COVID-19 or the corona virus causes anxiety for many Lithuanians, creating more stress in our daily lives. Such stress can manifest itself in apathy, frustration and unwillingness to do anything. Nevertheless, such an introduction of ecommerce opens up many opportunities for businesses to reach consumers they previously could not reach or were invisible to them.

The expansion of ecommerce removes spatio-temporal borders in the business world which consequently contributes to the agility and mobility of various enterprises in the global economy (Zoroja et al., 2020).

Such advantages are also reflected in the figures, according to Statista (2021) data generates more than $\$ 581.9$ billion from mobile apps alone and is projected to grow more and more. Despite positive forecasts, businesses are facing significant challenges, not only from a consumer perspective, when forced to move their services into the online space or trade through a new online platform during the pandemic.

According to Kumar et al. (2018) there is an effect on the speed of the internet data being provided due to the high demand in the consumption as people are more engaged to the video chats, online learnings and video conferencing tools which needs high speed of internet Business to Business (B2B) representatives face security concerns.

Hussain et al., (2021) make a research about Covid-19 impact on B2B ecommerce. Research results show that result technological factors have a significant positive relationship with B2B ecommerce in sports and surgical SMEs (small business enterprises). Competitive pressure as an environmental factor differs in sports and surgical SMEs to use B2B ecommerce. There are also other factors who effect B2B ecommerce.

According to Pejić-Bach (2021), the problems with the usage of video services emerged rapidly, mostly from the lack of security and privacy, curbing at least to some extent the initial enthusiasm and frustrations emerge. Such security failures or data leaks are an increasingly growing problem in today's society. Consumers disclose their private information to merchants when shopping online or responding to marketing campaigns despite their privacy concerns (Kolotylo-Kulkarni, Xia \& Dhillon. 2021).

Problems such as security failures encourage consumer mistrust and dissatisfaction with the services provided by online shops, while reducing the intention of purchases. 
DOI: 10.14807/ijmp.v12i6.1750

According to Ribeiro et al. (2021), marketing deals with satisfaction of consumer's needs and desires, generating profit for who does it, employing several tools and techniques to make the best out of the market, at the lower possible cost to the organization; achieving previously defined goals.

The increase in ecommerce research is observed in the context of the scientific literature. It examines developments in ecommerce during the pandemic period and analyses individual business areas and cases.

Shahzad et al. (2020), analyze covid-19 impact on Ecommerce usage at Malaysian healthcare industry. They collect 100 questionnaires samples from a healthcare provider, doctors, hospital management, medical assistant nurses, and medical supplier. The finding reveals that organization readiness, ecommerce knowledge, and supply chain integration have a significant positive impact.

Silimar research has been made in same region by Priambodo et al. (2021). Authors try to find out Ecommerce readiness of creative industry during the COVID-19 pandemic in Indonesia. The quantitative method has been applied as well a research approach by gathering questionnaires from 383 business owners.

Results show that technology readiness is seen as the most significant impact on a company's ability to cope with volatility, while environmental readiness constraints encourage businesses to adopt Ecommerce. In both research we can see similar results related with business readiness importance for online consumers.

According to da Silva, Sugahara and Ferreira (2021), in Brazil, companies linked to the Rede Brasil do Pacto Global and other organizations in the private sector acted to contain the disease in several ways, for example, with the creation of donation programs, credit lines and flexible working regimes, with the aim at reducing the displacement of workers and the consequent containment of the advance of the pandemic.

Guthrie, Fosso-Wamba and Arnaud (2021) make research about online consumer resilience during a pandemic. They try to find out exploratory study of ecommerce behavior before, during and after a COVID-19 lockdown. They said that COVID-19 pandemic has disrupted retail and accelerated the trend towards electronic commerce. They also explain that year-over-year growth in purchases of organic and natural products, such as cosmetics, therapy, herbal medicines, essential oils, and aromatherapy, as well as personal hair, body and face care, 
DOI: 10.14807/ijmp.v12i6.1750

makeup, and perfume, may be explained by a desire for some consumers to take one's mind away from the COVID-19 situation.

Similar results were found in Veeragandham et al., (2020) research. They found that consumers are more likely to continue online purchases Post COVID also as Online shopping creates hustle free efforts and easy to shop with different offers.

Aziz et at., (2021) look to this topic from other side. Instead of talking with the business they made a research related with one target groups. They try to find out the usage of Instagram and ecommerce platform during covid-19 among mothers. Results show that the cost and time efficiency as factors influencing the respondents' online purchase through social media. Also, they mansion that consumer can compare prices without feeling pressure.

Salem and Nor (2020) also make a research related with consumers. They try to find out the effect of covid-19 on consumer behavior in Saudi Arabia: switching from brick and mortar stores to ecommerce. A total of 190 valid responses were obtained and results show that government support significantly influenced consumer's intention to adopt ecommerce during the COVID-19 outbreak in Saudi Arabia. Data also show that perceived usefulness, risk taking propensity, perceived behavioral control perceived lack of alternatives. These two-research show that consumers are willing to buy from various online platforms, but also some those shops have a lack of alternatives.

Sharma (2020) make a research about ecommerce market in India after covid-19 pandemic. Results show that popularity of ecommerce increase after the advent of covid-19 pandemic by $17 \%$ and expected to rise further, sectors such as electronics, fashion and accessories, health and pharmacy did particularly well, with an average growth of $133 \%$ in sales.

Ghandour and Woodford (2020), research findings show that coronavirus has positively affected the Ecommerce industry as more retailers and consumers have shifted onto online channels for their buying and selling activities in UAE. Both researches show increased number of consumers during Covid-19 pandemic, also certain sectors like pharmacy, electronics and fashion was most successful.

We can that there is some differences between consumers in different regions. This could be related with traditions, habits or other type of traditional behavior, but in recent pandemic years this could be related with pandemic results in particular region. 
Veeragandham et al., (2020) found different results, they mansion that there is a noteworthy change in buyer's mentalities and shopping conduct, most of them are relied upon to remain post-pandemic. They found out that buying perception changed towards Ecommerce sites during the pandemic around $46 \%$ during the pandemic.

These results fulfil the gap in Harahap et al. (2021) research. Authors try to find out about emerging advances in Ecommerce. The main concern was consumer buying perception during covid-19 pandemic. The factors that influence panic buying that tends to make impulsive buying are psychological factors, environmental factors, regulation and trust. Good planning will limit the occurrence of impulsive purchases like, personal factors play a huge role in controlling buying behavior.

To sum up, the pandemic process has forced many businesses to relocate and expand their activities through electorate commerce. The range of services has expanded to give consumers new opportunities. It has become easier to perform many every day, work and scientific activities in the online space. Nevertheless, negative consumer and business prospects have emerged.

Consumers are often unable or unwilling to take advantage of the ecommerce opportunities offered to them due to the social and economic problems caused by the pandemic. Ensuring data security is becoming an increasingly important factor in ensuring a positive attitude of partners and customers towards e-business.

The pandemic has a huge impact on ecommerce and only the future of ecommerce will depend on consumer confidence and use.

\section{DATA AND METHODOLOGY}

\subsection{Research methodology}

According to Ribeiro et al. (2021) aspects such as age, occupation, lifestyle etc., are closely related to the individual and also have a strong influence on his purchasing. In Case study of Lithuania, we try to get as much information as possible about aspects such as age, occupation and lifestyle. In order to achieve the goal of this research we analyze different data sources from ecommerce related websites and statistics department of Lithuania to find out what's happening right now in Lithuania ecommerce environment. 
DOI: 10.14807/ijmp.v12i6.1750

We try to figure out how consumer behavior changes during pandemic year and what impact it did for entire industry. Results were compared with different type of scientific research results in other regions.

We try to compare and explain how Lithuanians change their habits towards ecommerce during pandemic years.

\subsection{Collected empirical data and results}

In a first picture we analyze data from persons who have bought or ordered goods or services online. Persons were divided by age and purchasing time in to different groups.

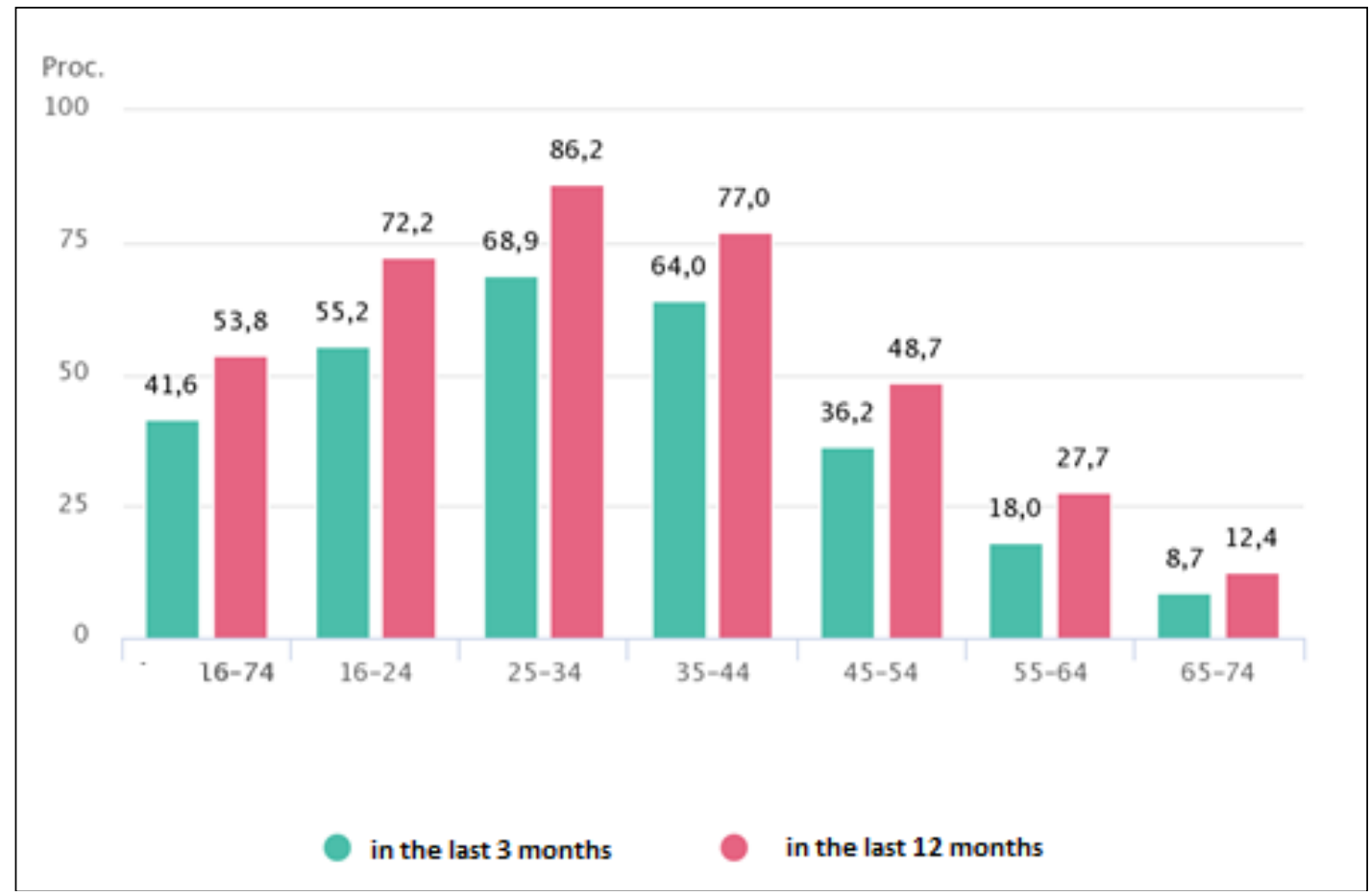

Figure 1: Persons who have bought or ordered goods or services online, by age group in 2020 Source: Statistics Department Lithuania, 2021

The total number of buyers reached 41.6 per cent of people who bought online in the last 3 months, which is 3.7 per cent more than in 2019. When comparing the frequency of 12month buyers, this indicator in 2019 reached 48.4 per cent, which is 5.4 per cent, less than in 2020. The largest number of buyers was in the 25-34 age groups.

According to the data of the Pigu.lt (2021), Lithuanian buyers, during quarantine, usually buy essential and luxury goods such as furniture, computer equipment or jewelry on the internet.

Although according to the data of Statistics Lithuania (2021), the largest share of consumers bought clothes, footwear, accessories. 
DOI: 10.14807/ijmp.v12i6.1750

The tendency of the population to buy online also depends to a large extent on factors such as developed internet infrastructure, cyber security and efficient logistics for the delivery of goods.

The highest purchasing activity was associated with the second wave in the fourth quarter of year, at which time the highest purchasing activity was visible. We can guess that business was ready to second wave and implement needed changes to online shops.

These buying behavior results could be explained by the Taylor (2021) study research indicates that episodes of panic buying typically last 7-10 days. He also adds that other forms of messaging are likely more effective in curbing panic buying, which was quite common in Lithuania at that days.

Xiao et al. (2020), research also found that the daily perceived uncertainty on COVID19 affected daily information overload, which in turn stimulated daily information anxiety, ultimately determining the daily impulsive buying.

Other consumer behaviour change could be related with digital marketing. Customer flows grow day by day despite the crisis, much bigger competition is also emerging, encouraging ecommerce to look for tools to attract customers.

According to MacDonald (2020) the tremendous growth of internet or digital marketing in developed countries has become the core of many organizations overall marketing strategies to achieve competitive advantage during the pandemic outbreak. These results could be seen in Lithuanian consumers groups divided by age.

Table 1: Percentage of persons who purchase product or services by internet in diferent age

\begin{tabular}{|l|c|c|c|}
\multicolumn{1}{l|}{ groups } \\
\hline All persons 16-74 year old & 2019 & 2020 & Change \\
\hline $16-24$ & $48,4 \%$ & $53,8 \%$ & $+5.4 \%$ \\
\hline $25-34$ & $68,1 \%$ & $72,2 \%$ & $+4.1 \%$ \\
\hline $35-44$ & $79,1 \%$ & $86,2 \%$ & $+7.1 \%$ \\
\hline $45-54$ & $65,6 \%$ & $77,0 \%$ & $+11.4 \%$ \\
\hline $55-64$ & $41,9 \%$ & $48,7 \%$ & $+6.8 \%$ \\
\hline $65-74$ & $25,7 \%$ & $27,7 \%$ & $+2 \%$ \\
\hline
\end{tabular}

Source: Lithuania statistical department, 2021

From the table above, it can be noted that the number of buyers has increased in all age groups.

The biggest increase, as much as 11.4\% observed in the 35-44 age group. It is also noted that the greatest growth is in those age groups that use the internet the most. As a result, we can 
DOI: 10.14807/ijmp.v12i6.1750

say that such a jump in purchases is potentially linked not only to the pandemic, but also to the greater investment of organizations in digital marketing.

Different results were found in Moon et al. (2021) research, where in terms of using offline distribution channels during the COVID-19 pandemic, it was found that men in their 20s and 30s tended to use offline distribution channels in S. Korea. Other research find similar results to MacDonald (2020), they also relate number changes to media interactions.

According to Koch (2020) research, results show that normative determinants such as media reports on the economic situation are related to consumers' purchase intentions, whereas the normative influence of close social networks is not. There results also can by applied to Lithuanian population.

According to Gemius Audience (2019) research more than 80 percent of people who use an internet also have a social network account in Lithuania. All these results can be explained by the sudden and temporary constellation at the level of the socio-technical regime during the pandemic.

Other huge factor in consumer buying behavior was a different restriction for foreign products. Some fast fashion companies announced that they would be canceling their orders soon after the government established the shutdown (Koch, 2020).

According to MacDonald (2020) people all over the globe are seeing considerable delays in-home deliveries across the board, with customers having to wait up to a week for an available delivery slot. That's why more people are linking to buy from local internet shops. Never the less according to Lithuania statistical department, during the quarantine period, over 100 new e-shops were established in Lithuania, which were opened by small and medium-sized business owners.

Most of these new e-shops are the result of the relocation of sales from physical stores, but there are also those that have been opened by business innovators of the country who have noticed new business niches. These intentions also show in Lithuania statistics department data (Figure 2).

Most Lithuanian buyers, regardless of age, were significantly more likely to buy or order goods from Lithuanian electorate stores than from other countries.

The highest 91.2 percent is in the 35-44 age group. 
DOI: 10.14807/ijmp.v12i6.1750

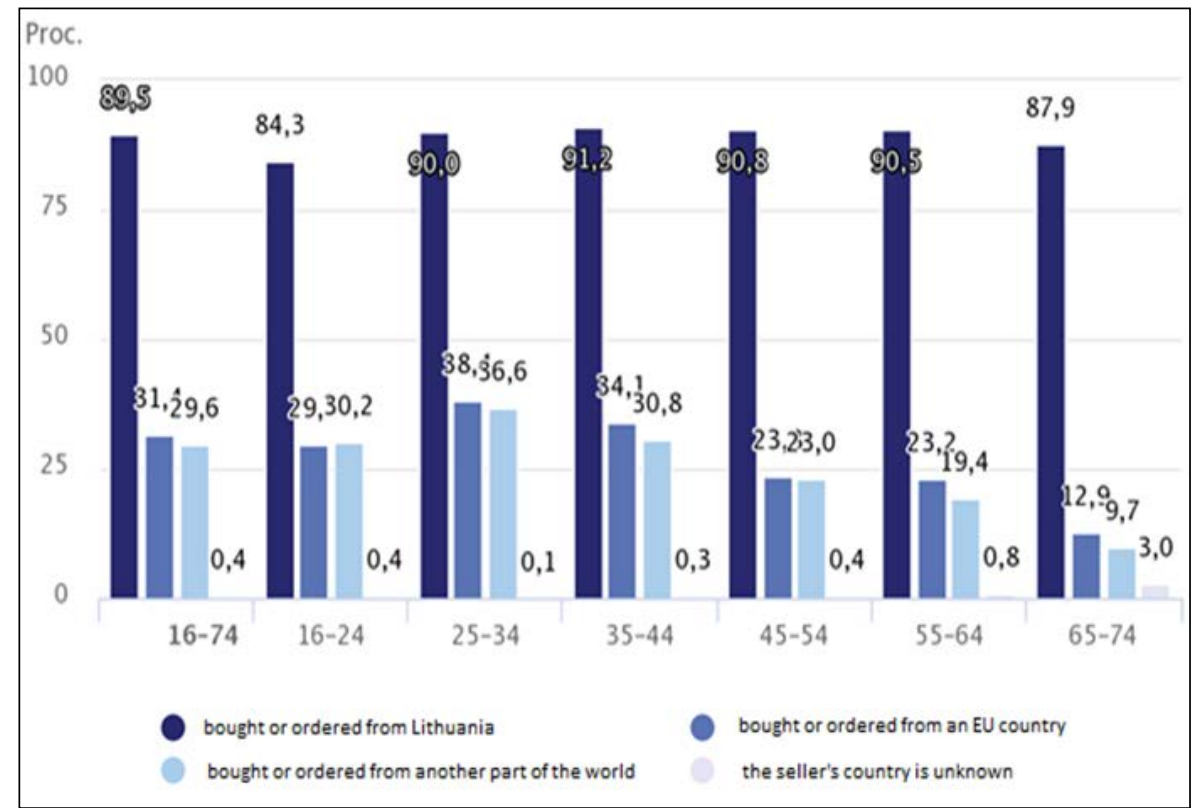

Figure 2: Persons who have purchased (ordered) goods or services online, by age and country of seller of goods or services in 2020

Source: Lithuania statistical department, 2021

The growth of this group's purchases compared to 2019 was the highest, so we can conclude that the new buyers were primarily buying from Lithuanian e-shops.

Shoppers aged 25-34 had the most purchases of a product or service from another EU country from all other age groups, at 38.4\%. Also, this age group mostly bought from other countries of the world that are not part of the EU. The lowest percentages of purchases in the EU and other countries were in the group aged 65-74.

According to Keane and Neal (2021) research related with pandemic and consumer panic that is that both foreign cases and the policy decisions of foreign governments contribute to domestic panic.

Different results were found in Topolko (2021) research statistical analysis show what the corona pandemic didn't have an impact on online shopping across the border. $67.9 \%$ of respondents are still shopping online across the Croatian border. $42.9 \%$ of respondents buy equally in Croatian and foreign web stores during COVID-19 pandemic according to Topolko (2021).

Carvalho et al., (2020) analysis show that transactions with foreign-owned cards cause an even greater negative contraction. So, we can see that according to different sources Covid19 pandemic had different type of impact for different markets. 
DOI: $10.14807 /$ ijmp.v12i6.1750

Another important highlight in consumer purchase intuition is the frequency of purchases. The frequency of purchases is related to the user experience and trust in the online store.

Tran (2021) confirms hypothesis that "Online customer pandemic fear positively moderates the relationship between economic benefits and sustainable consumption; such that economic benefits influence sustainable consumption more strongly when pandemic fear is higher".

Similar results were found in Naeem (2021) research related with social media interactions impact for consumer behavior. Findings reveal that uncertainties and insecurities proof, buying as persuasion, product unavailability proof, authorities' communication, global logic, and expert opinion are some of the causes on social media platforms that developed the situation of consumer panic buying during Covid-19 crises according to Naeem (2021). For example, in April, compared to the same period last year, Pigu.lt recorded an $80 \%$ increase.

According to data from the last quarter, e-shop sales grew by about 30 percent. These results could be seen in general Lithuanian consumer behavior.

Table 2: Persons who have purchased or ordered goods or services online

\begin{tabular}{|l|l|l|l|}
\hline & 2019 & 2020 & Change \\
\hline $1-2$ times & 44,2 & 40,6 & $-3,6 \%$ \\
\hline $3-5$ times & 39,2 & 36,8 & $-2,4 \%$ \\
\hline $6-10$ times & 10,9 & 13,6 & $+2,7 \%$ \\
\hline More than 10 times & 5,7 & 9,0 & $+3,3 \%$ \\
\hline
\end{tabular}

Source: Lithuania statistical department, 2021

As can be seen from the presented table, the results are mixed. The number of people who bought 1-2 times online decreased by 3.6\%, although the majority of such persons still remained $-40.6 \%$ of those who bought $3-5$ times also decreased by $2.4 \%$ to $36.8 \%$, which still represented a significant part of the overall online shopping market. In contrast to the number of people shopping 6-10 times, it increased by $2.7 \%$ to $13.6 \%$, but compared to the previous figures, the number of these persons is 2-3 times lower. The number of people shopping more than 10 times increased by even more than 3.3\% from 5.7\% to $9 \%$.

This may be due to consumer experience and trust in online shops, but it may also be the result of the consequences of the pandemic leading to more frequent shopping by consumers in the online shops.

Similar results were found in Wu et al. (2020) research on the Chinese online users who frequently use Taobao retail website and found the limited-quantity and time are the key 
DOI: 10.14807/ijmp.v12i6.1750

predictors for the perceived arousal, which subsequently resulted in the impulsive buying behavior.

Same results were found in Islam et. al (2021) research show that LQS (Limited Quantity Scarcity) and LTS (Limited Time Scarcity) significantly increase perceived arousal in consumers, which further leads to more impulsive and obsessive buying. All these results show that pandemic caused buying and delivery limitations make huge impact for consumer purchase frequency.

Another important subject is the amount of money spent. According to Naseri (2021) to "the retail industries are among the prominent casualties of the COVID-19 pandemic, as people adjust to the new normal of online shopping and working from home, which has lowered demand and business volume of the industry in the short term.”

Another important part is to know how much money consumer are willing to spend during the pandemic years, also change the amount of money before and after pandemic.

Topolko (2021) also add that there is a notable growth of online shopping in case of quantity and money spend. Lithuania statistical department results also indicate changes in money spend for commerce products and services.

Table 3: Amount of money spend for e.commerce products and services

\begin{tabular}{|l|c|c|}
\hline & 2019 & 2020 \\
\hline Less than 50 EUR & $25,8 \%$ & $20,9 \%$ \\
\hline 50-99 EUR & $28,7 \%$ & $23,0 \%$ \\
\hline 100-499 EUR & $35,8 \%$ & $45.2 \%$ \\
\hline 500-999EUR & $5,8 \%$ & $2,1 \%$ \\
\hline More then 1000 EUR. & $1,9 \%$ & $3,8 \%$ \\
\hline
\end{tabular}

Source: Lithuania statistical department, 2021

Changes in the trade sector are also clearly visible in Lithuania. According to Lithuania statistical department (2021) retail prices in December 2020, compared to September 2020. fell 0.1 percent. Expenditures up to EUR 100 are still the most frequently spent amount of money for online shopping in Lithuania, in 2019 the number of such people reached $54.5 \%$ and in 2020 this figure fell to $43.9 \%$. In contrast to the $€ 100-499$ cost of online spending, they have increased by $9.4 \%$. Fewer people spent 500-999eur. for online purchases, the share fell from $5.8 \%$ to $2.1 \%$. The number of people spending more than $€ 1,000$ increased from $1.9 \%$ to $3.8 \%$.

According to Lithuania statistical department (2021) ecommerce will grow, but for the time being it cannot match the losses incurred by companies in closing stores. To sum up, people's spending online is increasing, and more and more people are spending more money to 
DOI: 10.14807/ijmp.v12i6.1750

buy goods and services online. Reasons of this distribution also could be explained in different ways.

According to Thaworm et al., (2021) research the results show that, attitude, subjective norms, and perceived behavior control positively impact the consumers' online purchasing behaviors.

Tran (2021) related similar growing distribution with Covid-19 pandemic. His study finds a positive moderating effect of pandemic fear on the relationships among ecommerce platforms, economic benefits, and sustainable consumption.

Naseri (2021) results complements Tran (2021) results by adding that most Malaysian consumer buying attitude and behaviors have change in dramatically to online shopping during pandemic, where they belief and feel more convenience, save time, energy effective, safe and with restriction movement control order by government. These results show that covid-19 pandemic have significant impact on consumer purchasing behavior. People during pandemic spend more money online than before, because of government's restrictions and other security factors.

COVID-19 has significant impact on ecommerce of the world and in some cases negative impact but overall ecommerce is growing rapidly because of virus (Bhatti, et al., 2020). Virus change consumer daily habits. Consumers spend more time in Internet, buy more products, and spend more money than before.

Never the less they were more active in all age groups. Guthrie, Fosso-Wamba and Arnaud (2021) explain that with react-cope-adapt framework. Guthrie, Fosso-Wamba and Arnaud (2021) found that online consumers react, cope with, and then adapt to such stressful life events, thus validating the usefulness of the react-cope-adapt framework of constrained consumer behaviour in an online environment. Our findings also show the grow and expansion of ecommerce across regions, with consumers in emerging economies making the greatest shift to online shopping.

These results could be explained with Moon, Choe and Song (2021) study. They research results show that when people have enough knowledge of COVID-19, they actively perform self-protection measures, which leads to more online shopping. Business and consumers nowadays are facing many challenges by retailers in ecommerce, such as extend the delivery time, difficulty face during movement control, social distance and lockdown. These challenges could be a great future research idea. 
DOI: 10.14807/ijmp.v12i6.1750

\section{CONCLUSIONS}

Pandemic caused by the Covid-19 virus, affecting the entire ecommerce sector. The business had to adapt and move the main sales channels to the online space. Not all businesses were ready for this. Businesses had to offer a wider range of services in order to survive. The issue of cyber security has grown in this covid-19 period of time. Consumers have also reacted ambiguously to this situation. Not only are economic factors that determine the frequency or quantity of consumer purchases distinguished, but also social and psychological factors, such as loss of motivation or apathy. Nevertheless, in a general context, some business sectors and consumers have successfully adapted to the complete relocation to the online space. Regional and national studies carried out by different authors also show that sales are growing in the online space.

After reviewing the indicators of the Republic of Lithuania, it was noticed that the volume of online purchases in all age groups increased. The greatest increase was observed in the middle age group. The vast majority of Lithuanian shoppers were selling local online shops. Buying from European countries and online stores in other parts of the world differed minimally. The increase was also noticeable in the frequency of shopping, and the number of people shopping more times increased. The amount of money spent on online shopping has also increased. The pandemic has increased the scope of ecommerce and the range of services in Lithuania despite the deteriorating economic and social situation.

This study has a limitation in that it was conducted during June and July 2021, when COVID-19 was still rampant in society. Since confirmed cases of COVID-19 are still growing we can't ensure that these changes a final change in consumer behavior during pandemic. The recommendation for future work is more wide and detailed evaluation of the relevance of ecommerce impacts to the consumer behavior in the process of purchase from online websites in order to deepen even more social and economic, issues that concern both companies and consumers.

\section{REFERENCES}

Aziz, A. A., Rashid, R. M., \& Adnan, W. H. (2021). The usage of instagram and ecommerce platform during Covid-19 among mothers. Journal of Media and Information Warfare, 14(1), 107-122.

Balabash, O., Ilin, V., Poprozman, N., Kuznetsova, I., Shushpanov, D., \& Slavina, N. (2021). Content Strategy in Management of Communications. Independent Journal of Management \& Production, 12(3), s232-s242._DOI: https://doi.org/10.14807/ijmp.v12i3.1538 
Bhatti, A., Akram, H., Basit, H. M., Khan, A. U., Raza, S. M., \& Naqvi, M. B. (2020). Ecommerce trends during COVID-19 Pandemic. International Journal of Future Generation Communication and Networking, 13(2), 1449-1452.

Bickauske, D., Simanaviciene, Z., Jakubavicius, A., Vilys, M., \& Mykhalchyshyna, L. (2020). Analysis and Perspectives of the Level of Enterprises Digitalization (Lithuanian Manufacturing Sector Case). Independent Journal of Management \& Production, 11(9), 2291-2307.

Carvalho, B., Peralta, S., \& Pereira dos Santos, J. (2020). What and how did people buy during the Great Lockdown?

Černikovaite, M. E., \& Karazijienè, Ž. (2021). Social-economic effects of the COVID-19 pandemic in Lithuania. In The 20th International scientific conference" Globalization and its socio-economic consequences 2020", Zilina, Slovak Republic, October 21-22, 2020: Section: Global impact of COVID 19 on economy and society (1 - 10). EDP Sciences.

Da Silva, L. H. V., Sugahara, C. R., \& Ferreira, D. H. L. (2021). Corporate social responsibility in times of crisis: business actions during the COVID-19 pandemic. Independent Journal of Management \& Production, 12(4), 909-927.

Europos centrinis bankas (2021). Žvilgsnis ị praėjusius metus. Rertivied from https://www.ecb.europa.eu/pub/annual/html/ar2020 4960fb81ae.lt.html. Access: 02 July 2021.

Europos komisija (2021). Darbo vietos ir ekonomika koronaviruso pandemijos metu. https://ec.europa.eu/info/live-work-travel-eu/coronavirus-response/jobs-and-economy-duringcoronavirus-pandemic_lt. Access: 29 May 2021

Gemius (2019). Kiek žmonių Lietuvoje iš tiesų naudojasi socialiniais tinklais? Retrieved from https://www.gemius.lt/visos-naujienos/kiek-zmoniu-lietuvoje-is-tiesu-naudojasisocialiniais-tinklais.html. Access: 04 June 2021.

Ghandour, A., \& Woodford, B. J. (2020). COVID-19 Impact on Ecommerce in UAE. 2020 21st International Arab Conference on Information Technology (ACIT), 1-8. DOI: 10.1109/ACIT50332.2020.9300077.

Guthrie, Cameron, G., Fosso-Wamba, S., \& Arnaud, J. B. (2021). Online consumer resilience during a pandemic: An exploratory study of ecommerce behavior before, during and after a COVID-19 lockdown. Journal of Retailing and Consumer Services, 61, 102570. DOI: 10.1016/j.jretconser.2021.102570.

Ho, V. T., Phan, N. T., \& Le-Hoang, P. V. (2021). Impact of electronic word of mouth to the purchase intention-the case of Instagram. Independent Journal of Management \& Production, 12(4), 1019-1033.

Hussain, A., Shahzad, A., Hassan, R., \& Doski, S. A. (2021). COVID-19 impact on B2B ecommerce : A multi-group analysis of sports and surgical SME's. Pakistan Journal of Commerce and Social Sciences (PJCSS), 15(1), 166-195. Rertivied from http://hdl.handle.net/10419/233772. Access: 01 July 2021.

Kačerauskas, E. (2021). Rertivied from https://www.vz.lt/reshapebusiness/2021/02/25/kodel-daugiau-perkame-internetu-kaip-per-metus-pasikeite-saliesgyventoju-kasdienybe. Access: 05 July 2021. 
Karpenko, L., Zhylinska, O., Dmytrenko, H., Poprozman, N., \& Koltun, V. (2021). Synergetic Management Tools for Enterprise Economic Security. Journal of Security \& Sustainability Issues, 9(4), 1421-1430. DOI: https://doi.org/10.9770/jssi.2020.9.4(25).

Keane, M., \& Neal, T. (2021). Consumer panic in the COVID-19 pandemic. Journal of econometrics, 220(1), 86-105.

Koch, J., Frommeyer, B., \& Schewe, G. (2020). Online Shopping Motives during the COVID-19 Pandemic - Lessons from the Crisis. Sustainability, 12(24), 10247. DOI: https://doi.org/10.3390/su122410247.

Kolotylo-Kulkarni, M., Xia, W., \& Dhillon, G. (2021). Information disclosure in ecommerce: a systematic review and agenda for future research. Journal of Business Research, 126, 221-238. DOI: 10.1016/j.jbusres.2020.12.006.

Kumar, N., Anusara, J., Hossin, M. A., Sarkar, M. K., Chanthamith, B., Shah, S., \& Russel, M. I. H. (2018). Challenges and Opportunities of Ecommerce in India: Pathway for Sustainable Ecommerce. International Journal of Engineering, Business and Management (IJEBM), 2(2), 13-21.

MacDonald, O. B. (2020). Impact of Covid-19 pandemic on social media marketing and buying behavior of online grocery shoppers in Dublin Ireland (Doctoral dissertation, Dublin, National College of Ireland). Retrieved from http://norma.ncirl.ie/4729/1/okeinayebeliefmacdonald.pdf. Access: 01 July 2021.

Moon, J., Choe, Y., \& Song, H. (2021). Determinants of Consumers’ Online/Offline Shopping Behaviours during the COVID-19 Pandemic. International journal of environmental research and public health, 18(4), 1593. DOI: 10.3390/ijerph18041593.

Naeem, M. (2021). Do social media platforms develop consumer panic buying during the fear of Covid-19 pandemic. Journal of Retailing and Consumer Services, 58, 102226. DOI: https://doi.org/10.1016/j.jretconser.2020.102226.

Naseri, R. N. N. (2021). Issues And Challenges Of Online Shoppingactivities On The Impact Of Corona Pandemic: A Study On Malaysia Retail Industry. Turkish Journal of Computer and Mathematics Education (TURCOMAT), 12(10), 7682-7686.

DOI: https://doi.org/10.17762/turcomat.v12i10.5680.

Pejić-Bach, M. (2021). Electronic Commerce in the Time of Covid-19-Perspectives and Challenges. Journal of theoretical and applied electronic commerce research, 16(1), editorial. DOI: http://dx.doi.org/10.4067/S0718-18762021000100101.

Priambodo, I. T., Sasmoko, S., Abdinagoro, S. B., \& Bandur, A. (2021). Ecommerce Readiness of Creative Industry During the COVID-19 Pandemic in Indonesia. The Journal of Asian Finance, Economics and Business, 8(3), 865-873.

DOI:10.13106/jafeb.2021.vol8.no3.0865.

Ribeiro, R. E. M., de Sousa Oliveira, P. H., de Moura, K. B., de Abreu, C. R. S., de Sousa Ribeiro Filho, C. A., Monteiro, L. F. S., \& de Pontes Barbosa, D. J. B. (2021). Factors that influence the purchasing behavior of the consumer of natural products. Independent Journal of Management \& Production, 12(4), 979-996. DOI:

http://dx.doi.org/10.14807/ijmp.v12i4.1358.

Rudnichenko, Y., Dzhereliuk, I., Mykhalchyshyna, L., Savina, S., Pokotylova, V., \& Havlovska, N. (2020). Safe Interaction Management of State Institutions and Business Entities Based on the Concepts of Evolutionary Economics: Modeling and Scenario 
INDEPENDENT JOURNAL OF MANAGEMENT \& PRODUCTION (IJM\&P)

http://www.ijmp.jor.br

v. 12, n. 6, Special Edition ISE, S\&P - November 2021

ISSN: 2236-269X

DOI: 10.14807/ijmp.v12i6.1750

Forecasting of Processes. TEM Journal. Technology, Education, Management, Informatics, 2, 233-241.

Salem, M. A., \& Nor, K. M. (2020). The Effect of COVID-19 on Consumer Behaviour in Saudi Arabia: Switching From Brick and Mortar Stores to Ecommerce . International Journal of Scientific \& Technology Research, 9(07), 15-28.

Shahzad, A., Hassan, R., Abdullah, N. I., Hussain, A., \& Fareed, M. (2020). COVID-19 impact on ecommerce usage: An empirical evidence from Malaysian healthcare industry. Humanities \& Social Sciences Reviews, 8(3), 599-609. DOI: https://doi.org/10.18510/hssr.2020.8364.

Sharma, K. (2020). A surge in Ecommerce market in India after covid-19 pandemic. Gap gyan-a global journal of social sciences, 3(4), 54-57.

Statista: Worldwide mobile app revenues in 2014 to 2023 (in billion U.S. dollars). Internet access. Retrieved from https://www.statista.com/statistics/269025/worldwide-mobile-apprevenue-forecast. Access: 29 May 2021.

Taylor, S. (2021). Understanding and managing pandemic-related panic buying. Journal of Anxiety Disorders, 78, 102364. DOI: 10.1016/j.janxdis.2021.102364.

Thaworm, P., Wei, X., \& Wiriyawit, V. (2021). Analyzing consumers’buying behavior regarding online purchasing in Thailand. Journal of global business review, 23(1), 13-32.

Topolko Herceg, K. (2021). Impact of Covid-19 Pandemic on Online Consumer Behavior in Croatia. CroDiM: International Journal of Marketing Science, 4(1), 131-140.

Tran, L. T. T. (2021). Managing the effectiveness of ecommerce platforms in a pandemic. Journal of Retailing and Consumer Services, 58, 102287. DOI:

10.1016/j.jretconser.2020.102287.

Veeragandham, M., Patnaik, N., Tiruvaipati, R., \& Guruprasad, M. (2020). Consumer Buying Behaviour towards Ecommerce during COVID-19. International Journal of Research in Engineering, Science and Management, 3(9), 78-82. DOI:

https://doi.org/10.47607/ijresm.2020.292.

Wu, Y., Xin, L., Li, D., Yu, J., \& Guo, J., (2020). How does scarcity promotion lead to impulse purchase in the online market? A field experiment. Inf. Manag, 1-10. DOI: https://doi.org/10.1016/j.im.2020.103283.

Xiao, H., Zhang, Z., \& Zhang, L. (2020). A diary study of impulsive buying during the COVID-19 pandemic. Current Psychology, 1-13. DOI: https://doi.org/10.1007/s12144-02001220-2.

Zoroja, J., Klopotan, I., \& Stjepić, A. M. (2020). Quality of Ecommerce practices in European enterprises: cluster analysis approach. Interdisciplinary Description of Complex Systems, 18(2-B), 312. DOI: 10.7906/indecs.18.2.17. 